\title{
PENGARUH KEBEBASAN BERPENDAPAT DI SOSIAL MEDIA TERHADAP PERUBAHAN ETIKA DAN NORMA REMAJA INDONESIA
}

\author{
Shelma Mayolaika, Valerie Victoria Effendy, Christian Delvin, \& Mohammad Aqila Hanif \\ Institut Teknologi Bandung \\ Email: 13219037@std.stei.itb.ac.id
}

\begin{abstract}
Abstrak
Pada zaman serba teknologi kini, media sosial tidak dapat lagi dilepaskan dari rutinitas hidup manusia. Media sosial berperan penting dalam globalisasi dan masuknya budaya luar ke Indonesia karena melalui platform ini, manusia terhubung satu sama lain dalam konteks apapun tanpa terbatas waktu, tempat, dan subjek. Budaya luar masuk ke Indonesia dengan adanya kebebasan berpendapat mengenai topik apapun, baik maupun buruk, di media sosial. Dengan inilah kami melakukan penelitian untuk mengidentifikasi pengaruh kebebasan berpendapat mengenai budaya luar di media sosial terhadap perubahan etika dan norma masyarakat Indonesia, khususnya pada remaja karena anak mudalah yang paling aktif menggunakan sosial media. Metode yang digunakan dalam jurnal ini adalah dengan menganalisis data yang didapatkan dari studi literatur dan penyebaran angket. Dengan melakukan penelitian pada penulisan jurnal ini, didapatkan bahwa remaja di Indonesia mayoritas berpikiran terbuka dengan masuknya budaya luar (yang cukup menyimpang dari budaya Indonesia). Mayoritas remaja juga setuju bahwa kebebasan berpendapat di Indonesia sudah baik, tetapi seringkali tidak kenal batas. Berpendapat secara relevan tanpa mencampuri urusan hidup orang lain disetujui sebagai tindakan yang tidak apatis (terhadap budaya yang menyimpang). Pada akhirnya, dapat disimpulkan bahwa kebebasan berpendapat di media sosial dapat mengubah norma dan prinsip Indonesia dan negara ini harus siap menghadapi perubahan akibat globalisasi.
\end{abstract}

Kata Kunci: etika, globalisasi, kebebasan berpendapat, media sosial, remaja

\begin{abstract}
In this digital era, social media can no longer be separated from our daily life. Social media plays an important role in globalization and the exchange of foreign cultural values to Indonesia because through this platform, humans are connected to each other without being limited by time, place, and subject. Through the freedom of speech allowed on social media, any foreign cultural values, either good or bad, can spread and influence Indonesian users. This is why we conduct this research to identify the influence of freedom of expression on social media regarding foreign culture on change in ethics and norms of Indonesian society, especially on teenagers because young people use social media the most. The method used in this journal is by analyzing the data obtained from the study of literature and the distribution of questionnaires. By conducting research on the writing of this journal, it was found that the majority of teenagers in Indonesia are open-minded with the inclusion of foreign cultures (which are quite deviant from Indonesian culture). The majority of teenagers also agree that freedom of expression in Indonesia is already guaranteed, but often knows no boundaries. Giving opinion without interfering with other people's lives is approved as an act of not being apathetic (towards a deviant culture). It can be concluded that freedom of expression on social media can and has changed the norms and principles in Indonesia and this country must be prepared to face changes due to globalization.
\end{abstract}

Keywords: ethics, freedom of speech, globalization, social media, youth

\section{PENDAHULUAN}

Penggunaan media sosial bukan lagi menjadi hal yang baru bagi masyarakat Indonesia. Mulai dari untuk saling berkomunikasi dengan satu sama lain, bertukar informasi, berjualan, sampai berlomba dalam tren. Semua dapat dicari dengan adanya media sosial. Dalam kasus ini, hal yang menjadi topik utama dalam pembahasan adalah penggunaan media sosial dalam beropini, sangkut pautnya terhadap kebebasan berpendapat, dan 
dampaknya pada norma dan budaya yang berlaku di Indonesia.

Media sosial, sebuah platform serbaguna, bertujuan untuk menghubungkan satu sama lain dalam konteks apapun secara netral dan tidak terbatas waktu, tempat, dan subjek. Tentunya, dengan kapabilitas sebesar itu, media sosial berperan penting dalam globalisasi dunia luar ke dalam Indonesia. Meskipun ada kemudahan masuknya budaya luar tersebut, tidak semua budaya dapat dengan baik diterima masyarakat di Indonesia. Hal ini adalah salah satu faktor terjadinya perdebatan opini yang biasanya muncul karena adanya perbedaan pandangan, kebiasaan, kultur, dan hal lainnya. Tidak jarang perdebatan akan dimulai ataupun diakhiri dengan komentar yang menyakiti, vulgar, atau hal yang tidak relevan lainnya. Sebagai contohnya, pengguna media sosial dapat memberikan komentar jahat yang mengandung slurs terhadap pengguna lainnya karena kultur mereka yang tidak ada/ tabu di Indonesia.

Kenetralan dan kebebasan
berpendapat dalam media sosial menjadi senjata bermata dua untuk penggunanya. Tanpa adanya hukum dan etika yang ketat dalam bermedia sosial, pengguna 100\% dapat melakukan apapun, termasuk melakukan hal yang tidak baik dan merugikan orang lain seperti pada contoh sebelumnya. Jika terjadi hal seperti itu, sudah dipastikan media sosial bukan tempat yang aman untuk siapapun.

Beruntungnya, developer media sosial menyadari permasalahan ini. Semua media sosial sudah memiliki guidelines dan fitur report yang dapat meminimalisasi adanya aktivitas yang menyimpang. Salah satunya adalah melaporkan komentar dan post yang bersifat cyberbullying dan konten yang tidak relevan.

Permasalahan muncul dari kurangnya kinerja dari fungsi report tersebut. Tidak ada yang bisa menyalahkan media sosial karena media sosial hanyalah sebuah algoritma yang butuh input dari pengguna untuk dapat bekerja. Program hanya bisa membedakan mana yang baik dan mana yang buruk sesuai dengan perintah dari pengguna. Jika pengguna menginput sesuatu yang buruk dan mengkategorikan sebagai baik, program tentunya akan mengikuti instruksi dari pengguna dan mengkategorikan hal tersebut sebagai baik. Hal tersebut menjadi landasan mengapa kita, sebagai pengguna, menjadi subjek topik yang akan dibahas dan tidak menjadikan media sosial sebagai pelaku yang memunculkan masalah tersebut. Pengguna, dalam memasukkan input ke program (sebagai contoh komentar, post, atau hal lainnya), perlu memiliki pertimbangan terlebih dahulu apakah input tersebut sudah sesuai atau belum.

Dalam berpendapat, tentunya ada batasan dan pertimbangan. Karena tiap negara memiliki budaya, pandangan, dan kebiasaan yang berbeda-beda, bukan berarti sesuatu yang "menyimpang" bisa kita anggap salah dan ditolak semena-mena dengan komentar yang jahat. Meskipun ada batasan dan pertimbangan dalam beropini, bukan berarti tidak ada kebebasan dalam berpendapat. Topik tersebut menjadi hal yang menarik untuk dibahas sehingga di dalam esai ini, akan dibahas kebebasan berpendapat dalam penggunaan media sosial yang mengacu kepada norma yang berlaku di Indonesia.

Media sosial terbagi menjadi 6 jenis menurut Kaplan dan Haenlein, yaitu jejaring sosial, forum, blog, wiki, konten, dan dunia virtual. Jenis yang akan difokuskan pada pembahasan penelitian ini adalah jejaring sosial, blog, dan konten. Jejaring sosial adalah sebuah tempat di mana para pengguna dapat berinteraksi, berkomunikasi, dan bertukar informasi secara online. Blog adalah sebuah tempat bagi pengguna untuk menyampaikan buah 
pikirannya secara bebas dalam sebuah situs online yang biasanya milik pribadi atau milik bersama (institusi atau komunitas). Konten adalah bentuk karya dari para pembuat yang ingin menyampaikan pikiran dan pendapatnya melalui media yang bisa berbentuk tertulis, lisan, maupun video.

Media sosial yang kini sering dipakai di kalangan anak muda adalah Instagram, Twitter, dan Tiktok. Ketiga hal ini merupakan jejaring sosial yang memuat berbagai jenis konten mulai dari tulisan hingga video. Dalam tiga jejaring sosial ini, setiap pengguna yang sudah registrasi dan memenuhi syarat usia yang ditentukan dapat dengan bebas menyampaikan pendapatnya asalkan tidak melanggar peraturan-peraturan yang sudah ditetapkan masing-masing media sosial. Pendapatnya dapat disampaikan melalui konten atau komentar pada konten.

Perubahan sosial menurut William F. Ogburn adalah perubahan yang terjadi pada budaya immaterial (tidak ada wujudnya) karena disebabkan oleh kebudayaan material (ada wujud). Dalam konteks media sosial, perubahan berwujud ini didatangkan dari konten-konten yang setiap hari dikonsumsi oleh penggunanya. Kontenkonten yang mengandung nilai budaya berbeda dengan budaya lokal akan mempengaruhi budaya immaterial seperti pola pikir dan cara pandang orang yang melihatnya. Perubahan terjadi dalam norma dan etika masyarakat, pola perilaku masyarakat, dalam pemegang kekuasaan dan cakupan kekuasaan serta wewenang, dan dalam interaksi antar manusia. Perubahan sosial ini dapat terjadi dalam waktu yang instan dan singkat, tetapi ada juga yang terjadi dalam rentang waktu yang panjang.

Freedom of Speech merupakan salah satu dari sekian banyak HAM yang ditetapkan pada Universal Declaration of Human Rights oleh PBB. Berdasarkan definisi yang tertera pada Undang Undang
No. 9 Tahun 1998, kemerdekaan menyampaikan pendapat merupakan suatu hak yang dimiliki setiap warga negara untuk menyampaikan pikiran dalam bentuk lisan, tulisan, dan sebagainya secara bebas dan bertanggung jawab sesuai dengan ketentuan peraturan perundang-undangan yang berlaku (Presiden RI, 1998) (Nurgiansah, 2021).

Meskipun setiap orang bebas menyampaikan pendapat, terdapat beberapa batasan dalam menyampaikan pendapat yang diberlakukan oleh negara untuk menjaga agar kebebasan berpendapat satu pihak tidak membatasi kebebasan pihak yang lain. Pembatasan tersebut tertera secara mendetail pada KUHP (Nurgiansah, 2020).

Pembatasan kebebasan pendapat dalam KUHP: (1) pasal 207, 208, 209 mengenai penghinaan thdp penguasa dan badan usaha umum; (2) pasal 310, 311, 315, 316 , penyerangan atau pencemaran kehormatan atau nama baik seseorang dgn tulisan; (3) pasal 317, fitnah, pemberitahuan palsu, pengaduan palsu: (4) pencemaran nama baik orang mati.

Etika berasal dari bahasa Yunani, ethos dan ethikos. Ethos memiliki arti seperangkat kepercayaan moral, adat, sikap, watak, kebiasaan, cara berpikir, dan karakteristik dari seorang individu atau kelompok. Ethikos sendiri memiliki arti dibentuk dari kebiasaan, susila, tindakan dan perbuatan baik. Etika adalah ukuran baik dan buruk sebuah tindakan manusia. Hal yang baik didasarkan pada kebiasaan sebuah masyarakat sehingga etika di setiap tempat dapat berbeda-beda. (Lorens bagus, kamus filsafat (Jakarta: PT Gramedia pustaka, 2000), h.217) (Nurgiansah, 2018).

Menurut K Bertens dalam bukunya yang berjudul "Etika", etika terbagi menjadi tiga sudut pandang, yaitu etika sebagai praktis, refleksi, dan ilmu. Etika praktis berarti etika yang harus dipraktikkan, terlepas dari dipraktikkannya atau tidak. 
Etika praktis memiliki pengertian yang sama dengan moral, yaitu nilai yang membedakan perbuatan baik dan buruk manusia. Etika refleksi berkaitan dengan pemikiran moral di mana manusia memikirkan apa yang sebenarnya baik dilakukan atau tidak baik dilakukan. Etika sebagai ilmu membahas mengenai alasan mengapa kita mengikuti suatu ajaran moral dan bagaimana kita bersikap menghadapi moral yang beragam. (K Bertens, Etika, (Jakarta: Gramedia, 1993), h. 27).

Asmaran mengemukakan di dalam bukunya yang berjudul "Pengantar Studi Akhlak" bahwa etika adalah aturan bersikap dan berperilaku seorang individu yang hidup dalam masyarakat. Etika adalah sebuah prinsip untuk membedakan yang benar atau salah, baik atau buruk. Manusia hidup berdampingan sehingga etika yang benar harus dijalankan agar kehidupan bermasyarakat bisa berjalan dengan harmonis. Kalau tidak ada etika dalam bermasyarakat, kehidupan bisa seperti di neraka atau seperti di rimba di mana yang kuat menang dan yang lemah kalah. (Asmaran As, Pengantar Studi Akhlak, (Jakarta: PT Raja Grafindo,2002), cet. ke-3, h.7).

Dalam berkomunikasi, tentunya ada etika yang harus dijaga agar informasi yang ingin disampaikan dapat dikomunikasikan dengan efektif dan efisien. Menurut Nilsen (Johannesen, 1996), ada beberapa sikap yang harus diperhatikan dalam berkomunikasi. Pertama, seseorang harus menghormati dan menghargai orang lain sebagai seorang individu tanpa memandang status, usia, atau hubungannya dengan individu tersebut. Semua orang berhak dihormati dan dihargai pendapatnya dengan objektif. Kedua, pendapat, ide, perasaan, dan integritas orang lain harus dihargai. Ketiga, seseorang harus menjadi individu dengan pikiran terbuka, objektif, dan penuh toleransi (memperbolehkan) untuk mendukung kebebasan berekspresi orang lain. Keempat, menghargai pendapat dan berpendapat dengan bukti dan pertimbangan yang rasional. Kelima, mendengarkan pendapat orang lain dengan seksama terlebih dahulu sebelum mengambil keputusan untuk setuju atau tidak setuju.

Dalam menggunakan media sosial, setiap individu harus memiliki etika kontemporer, yaitu etika di dalam ranah elektronik, digital, atau online. Etika dalam media sosial mencakup sikap, tata cara, kebiasaan yang berkembang seiring dengan majunya teknologi. Etika elektronik berbeda dengan etika sehari-hari karena di media sosial seorang individu dihadapkan dengan berbagai macam budaya yang sangat luas dan global berkat adanya perkembangan teknologi. Orang tersebut harus bisa menentukan sikap yang tepat terhadap variasi budaya tersebut yang tentunya tidak semuanya sesuai dengan budaya lokal yang sudah dikenal.

Etika dalam media sosial menyangkut sikap yang dilakukan dengan penuh kesadaran, penuh tanggung jawab, penuh kejujuran, dan perbuatan bajik yang mendatangkan kebaikan bagi diri sendiri maupun sekitar. Etika di atas ini harus diterapkan dalam berinteraksi, berpartisipasi, berkolaborasi, berpendapat, hingga bertransaksi secara digital.

Kesadaran dalam bersikap artinya seorang individu tahu betul apa yang ia lakukan serta memiliki tujuan yang jelas dalam melakukannya. Media digital yang sangat cepat dan dapat bersifat anonim ini seringkali mendorong penggunanya untuk bertindak tanpa sadar atau berpikir lebih jauh. Misalnya adalah kebiasaan langsung menggunakan handphone "tanpa sadar" saat bangun tidur, kebiasaan meninggalkan komentar yang tidak relevan atau kurang membangun "tanpa sadar", dan kebiasaan membagikan informasi yang belum dipastikan kebenarannya "tanpa sadar". Tentu perbuatan di atas ini bukanlah 
perbuatan yang bijak sehingga seorang individu diingatkan untuk memiliki etika kesadaran dalam bersosial media.

Tanggung jawab dalam bersikap di sosial media datang bersamaan dengan sikap kesadaran karena kalau seorang individu tahu dengan jelas apa yang ia lakukan, ia pasti juga konsekuensi apa yang harus ia terima. Kejujuran dalam bersikap di sosial media sangat penting dimiliki karena dalam media digital, kebenaran sangat mudah dimanipulasi. Contohnya adalah dengan mengunggah konten yang tidak sesuai dengan fakta untuk menarik penonton. Hal yang terakhir adalah kebajikan dalam bersikap, yaitu bertindak dengan bijak untuk mendatangkan manfaat, kebaikan, dan menghargai kemanusiaan orang lain.

Menurut Tomlinson, globalisasi adalah suatu penyusutan jarak yang ditempuh dan pengurangan waktu dalam menjalankan berbagai aktivitas keseharian, baik secara fisik (sebagai contohnya berkunjung ke negara tersebut lalu membawa kebiasaan ke negara asal) atau secara perwakilan (seperti timbal balik informasi dan gambar menggunakan media elektronik), untuk "menghilangkan" kedua pemisah tersebut. (sumber: 4 Tomlinson, J. 1999. Globalization and Culture. Cambridge. Polity Press.)

Beberapa definisi yang diambil dari Scholte adalah sebagai berikut:

1. Internasionalisasi. Globaasi meningkatkan aktivitas hubungan internasional. Walaupun masingmasing negara masih mempertahankan identitasnya, negara tersebut menjadi saling bergantung satu sama lain.

2. Liberalisasi.

3. Universalisasi. Globalisasi dikaitkan dengan semakin luasnya penyebaran material dan immaterial ke seluruh dunia sebagai contoh pengalaman berkunjung.
4. Westernisasi. Diartikan dengan semakin luasnya penyebaran budaya dan cara berpikir yang berpengaruh secara global.

5. Hubungan transplanetari dan suprateritorialiti.

\section{METODE PENELITIAN}

Pada penulisan jurnal, para penulis melakukan survey dengan kuesioner luring yang ditargetkan kepada remaja di Indonesia (terutama di lingkungan kampus Jabodetabek untuk kemudahan pengumpulan data) sebagai landasan dalam menjawab rumusan masalah dan memenuhi tujuan dari penulisan. Pengumpulan data dilakukan dengan menggunakan Google Form sebagai alat mengumpulkan data responden. Untuk landasan teori yang dapat menjadi pendukung dalam menjawab kajian pada data analisis, para penulis sepakat untuk melakukan studi literatur terhadap beberapa jurnal yang dapat diakses dengan bebas di internet.

\section{HASIL PENELITIAN DAN PEMBAHASAN Hasil Penelitian}

\section{Batasan dan Keleluasaan Hak Kebebasan Berpendapat pada Media Sosial di Indonesia}

Indonesia adalah negara hukum. Masyarakatnya terikat oleh hukum untuk semua hal yang dilakukan oleh masyarakat. Tidak terkecuali aktivitas di media sosial. Hukum di Indonesia juga mengikat media sosial, berpendapat di media sosial, dan lainnya. Hukum yang mengatur tersebut adalah UU ITE. Selain tertulis, juga ada norma dan etika yang tertanam pada budaya di Indonesia. Norma dan etika adalah hal yang fleksibel karena merupakan dasar dari manusia untuk berinteraksi terhadap sesama manusia ataupun dengan lingkungan di sekitarnya. Memiliki kebebasan dalam melakukan sesuatu bukan berarti tidak ada batasan. Selama manusia 
hidup dengan manusia lainnya, manusia saling bertanggung jawab terhadap hak dan kewajiban orang lain, bukan hanya dirinya sendiri.

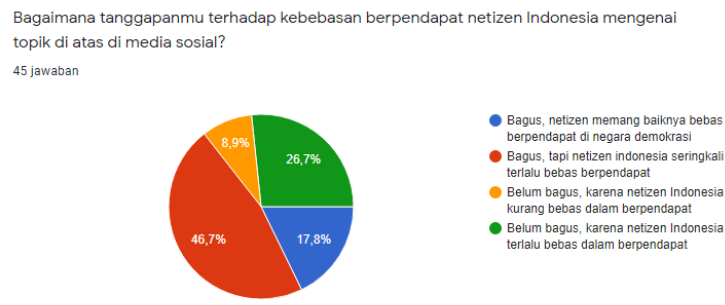

Gambar 1. Pie Chart Kebebasan Berpendapat

Pelanggaran dalam berkomentar biasanya terjadi karena adanya pandangan dari satu orang ke orang lainnya. Salah satu pemicunya adalah budaya luar, yang masuk karena globalisasi dan media sosial, yang menyimpang dengan budaya di Indonesia. Responden yang ditargetkan pada survey adalah remaja yang mengetahui/ membaca/ telah mengulik topik budaya luar tersebut. Sebanyak 82.2\% telah membaca topik LGBTQ+ dan $82.2 \%$ telah membaca mengenai kehidupan yang dipengaruhi oleh budaya barat. Akan tetapi, meskipun sudah menyadari keberadaan topik tersebut (budaya yang tidak sesuai dengan budaya di Indonesia) masuk ke Indonesia, mayoritas remaja di Indonesia (sekitar 53.3\%) memilih bahwa topik tersebut sudah tidak harus menjadi hal yang tabu dan sudah setuju bahwa Indonesia sudah harus memeluk kenyataan negara harus siap menghadapi perubahan.

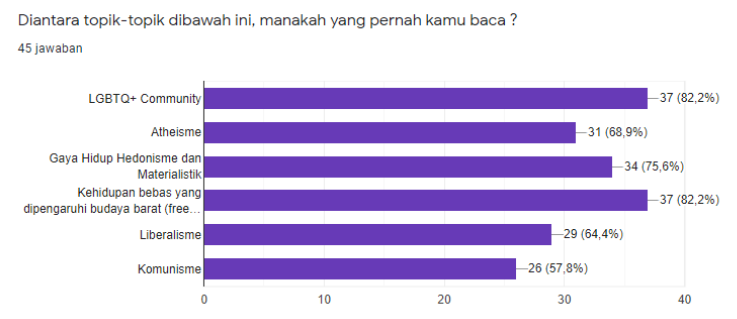

Gambar 2. Diagram Batang Topik

Menurut responden, $82.2 \%$ setuju bahwa komentar yang tidak relevan adalah menyinggung untuk individu lainnya dan tidak terbatas SARA saja, misalnya adalah bentuk tubuh, penyakit, dan lain-lain. Responden lain (77.8\%) setuju bahwa komentar yang tidak relevan adalah yang memaksakan pendapat dan 68.9\% lainnya setuju bahwa komentar yang tidak relevan adalah memulai kericuhan. Lalu, mayoritas setuju bahwa berpendapat dengan relevan bukan berarti bersifat apatis. Jika mengambil salah satu pendapat yang dapat mewakilkan mayoritas opini responden, komentar "Sebenarnya tergantung dengan konteks. Kita boleh saja mengingatkan bahwa perbuatan yang bersangkutan "menyimpang" dari kebiasaan, tetapi kita harus memiliki aturan dalam berpendapat seperti tidak boleh men-judge kehidupan pribadi atau privasi terlepas dari perbuatannya" cukup untuk memberikan alasan yang tepat.

Dengan kata lain, netizen di Indonesia sudah seharusnya siap dengan masuknya budaya barat di Indonesia (meskipun tidak biasa di Indonesia) dan ada batasan penting dalam berkomentar, yaitu tidak menyinggung orang lain. Ini sesuai dengan landasan teori, karena media sosial adalah salah satu bukti dari globalisasi dan adalah salah satu platform globalisasi, secara tidak langsung akan berefek terhadap pertukaran budaya antar negara. Jika ingin bermedia sosial, berarti pengguna harus siap dengan globalisasi itu sendiri.

\section{Pembahasan}

Dampak Positif dan Negatif Penggunaan Media Sosial terhadap Norma dan Budaya di Indonesia Memperluas Koneksi serta Cara Pikir Media sosial memudahkan masyarakat Indonesia untuk berinteraksi dengan sangat banyak orang dari berbagai budaya dan latar belakang. Ini menyebabkan masyarakat kita memiliki koneksi yang lebih luas sehingga lebih teredukasi mengenai isu-isu global. 
Masyarakat jadi lebih banyak tahu dan mengenal budaya lain sehingga tentu saja pikirannya lebih terbuka. Hal-hal yang jarang dibahas di Indonesia kini menjadi topik yang dikenal dengan luas oleh masyarakat kita. Misalnya topik mengenai kebebasan memilih gender (LGBT), kebebasan atas tubuh sendiri (free sex dan night life), kebebasan untuk tidak beragama (atheis), kebebasan memilih cara pandang politik (komunisme), dan berbagai macam lainnya.

Menurut 53.3\% responden, topiktopik di atas ini seharusnya tidak lagi dipandang tabu oleh masyarakat kita karena Indonesia harus mengikuti perubahan zaman. $24.4 \%$ lainnya menganggap topik di atas masih tabu, tetapi harus mulai dinormalisasikan sedangkan $20 \%$ lainnya menganggap topik tersebut masih tabu dan sebaiknya tetap tabu. Data ini menunjukkan bahwa sebagian besar anak muda di Indonesia sudah berpikiran terbuka untuk mengenal budaya luar dan berpendapat bahwa harus ada pergeseran di dalam norma negara ini supaya dapat lebih menerima budaya luar yang "menyimpang" tersebut.

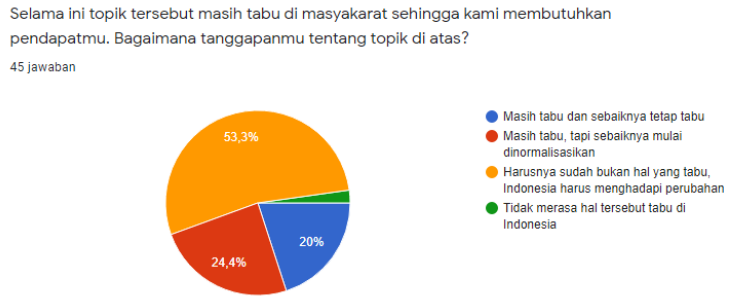

\section{Gambar 3. Pie Chart Ketabuan Topik}

Keterbukaan pikiran anak muda Indonesia zaman sekarang ini maksudnya bukan menerima dan menyetujui secara mentah budaya luar tersebut, tetapi lebih ke arah menyadari bahwa setiap individu hidup dengan prinsipnya masing-masing. Maka, orang tidak berhak menghakimi pilihan hidup orang lain. $82.2 \%$ responden berpendapat bahwa berkomentar secara relevan di sosial media, yaitu berkomentar dengan tidak mencampuri hidup orang lain terlepas pilihan hidupnya menyimpang atau tidak adalah hal yang tidak apatis. Salah satu responden memberikan pendapatnya bahwa "Saya ambil dari sudut pandang yang positif, di mana tidak merugikan orang lain, lebih baik netizen tidak usah banyak berkomentar. Akan tetapi, apabila sifatnya merugikan orang lain dan diri sendiri atau sudah melanggar, maka perlu dikomentari dengan catatan sewajarnya, menegur, mengingatkan, dan bukan menghakimi." Responden lainnya berpendapat bahwa tidak mengomentari pilihan hidup orang lain tidak apatis karena "justru dengan kita tidak mencampuri urusan orang kita secara tidak langsung menghargai orang tersebut."

Beberapa lainnya berpendapat bahwa tidak mengomentari kehidupan pribadi orang lain walaupun menyimpang merupakan tindakan apatis. Salah satu responden berpendapat bahwa mengomentari prinsip hidup orang lain yang menyimpang dari norma adalah hal yang harus dilakukan karena "sebagai bangsa yang menjunjung kesatuan dan persatuan, masyarakat Indonesia harus memiliki sikap peduli terhadap sesama dengan memberikan kebenaran yang bersifat fakta untuk meluruskan hal-hal yang salah." Data dari 2 sisi responden menunjukkan bahwa sebagian besar anak muda Indonesia memiliki pikiran yang terbuka dan luas terhadap budaya luar yang mungkin berbeda atau "menyimpang" dari budaya lokal. Sebagian besar berpendapat bahwa lebih baik tidak mengomentari prinsip hidup orang lain yang mungkin "menyimpang" dengan syarat prinsip tersebut tidak merugikan diri sendiri atau orang lain.

\section{Bebas Berekspresi}

$46.7 \%$ responden berpendapat bahwa kebebasan berpendapat mengenai topik LGBTQ+, free sex, atheisme, 
hedonisme \& materialisme, liberalisme, dan komunisme di Indonesia sudah bagus, tapi netizen indonesia seringkali terlalu bebas berpendapat. Data ini menyatakan bahwa media sosial memungkinkan setiap orang untuk bebas memberikan tanggapan atau pendapat mereka mengenai suatu hal tanpa terbatas oleh apakah tanggapan tersebut tabu atau tidak di Indonesia. Namun, kebebasan berekspresi ini bisa menjadi hal yang buruk dan merugikan orang lain bila tidak dibatasi. Kebebasan berpendapat tidak boleh sampai menyinggung, memaksakan pendapat, mengatur, dan memulai kericuhan atau konflik.

\section{Rentan dipengaruhi dengan Hal Buruk}

Media sosial memungkinkan informasi apapun tersebar secara luas di internet tanpa menyaring apakah konten tersebut baik atau buruk. Konten baik tentunya akan bermanfaat bagi penggunanya, tapi konten buruk tentu akan merugikan (Rachman, Ryan, et al., 2021). Konten seperti ini berpengaruh besar pada orang yang belum bisa memilah mana yang baik dikonsumsi dan mana yang lebih baik dihindari, khususnya adalah pada anak muda yang seringkali sedang dalam fase ingin mencari tahu dan mencoba segala hal terlepas dari apakah hal tersebut sesuai dengan norma di Indonesia atau tidak. Contohnya adalah budaya free sex yang sekarang mulai lebih sering terlihat di kalangan anak muda (Rachman, Nurgiansah, et al., 2021). Kalau budaya luar seperti ini sering dilihat, dikenali dan lama kelamaan dinormalisasi tanpa edukasi yang tepat, hal ini bisa merugikan bagi yang mempraktekkannya. Misalnya free sex tanpa edukasi seks yang tepat dapat menyebabkan penyakit HIV atau AIDS bagi pelakunya. Selain berpengaruh pada individu, tentunya budaya luar ini dapat mengubah norma di Indonesia mengenai menjaga kekudusan sampai pernikahan.

\section{Menimbulkan Kericuhan}

Selain berdampak negatif pada individu, berpendapat dengan bebas mengenai topik-topik di atas juga dapat menimbulkan kericuhan pada antar individu atau masyarakat. Misalnya ada seseorang yang dengan bebas menyebarkan ajaran atheisme. Tentu ada pihak yang setuju bahwa atheisme tidak apa-apa karena itu pilihan hidup masing-masing orang dan tidak merugikan orang lain, tetapi ada juga pihak yang tidak setuju karena kepercayaan tersebut melanggar sila pertama Pancasila sebagai pedoman hidup bangsa. Perbedaan pendapat seperti ini bisa menjadi perdebatan yang panas hingga akhirnya menyebabkan kericuhan dan perpecahan. Keributan di media sosial cenderung lebih parah dan tidak bermoral dibandingkan keributan di dunia nyata mengenai topik yang sama karena di dunia digital, identitas seseorang bisa disembunyikan dan orang tersebut bisa bebas mengatakan apapun tanpa takut akan konsekuensinya. Hal ini menyebabkan perilaku yang dilakukan di media sosial cenderung lebih kasar, kurang ajar, dan tidak menghargai. Hal ini mengakibatkan perubahan norma kesopanan di dalam hidup masyarakat Indonesia menjadi lebih buruk.

\section{Menurunnya Privasi}

Dalam media sosial, privasi adalah hal yang langka karena sekalinya seseorang mengunggah informasinya di internet, informasi tersebut sudah menjadi konsumsi publik, mau tidak mau, suka tidak suka. Netizen bebas berpendapat dalam mengomentari konten apapun yang ada walaupun komentar yang dilontarkan seringkali tidak relevan. Contoh komentar yang tidak relevan menurut para responden adalah komentar yang menyinggung, memaksakan pendapat, menasihati walau tidak diminta, mengatur, dan memulai kericuhan. Biasanya jenis komentar di atas 
inilah yang mengganggu privasi orang lain sehingga salah satu responded berpendapat bahwa "tidak mencampuri hidup orang lain merupakan bentuk penghormatan dan menghargai privasi."

\section{Penerimaan Budaya Luar yang Menyimpang Budaya di Indonesia}

Melihat dari hasil survey yang dilakukan, sebagian besar responden berpendapat bahwa "Harusnya sudah bukan hal yang tabu, Indonesia harus menghadapi perubahan". Dari sini dapat diartikan bahwa masyarakat Indonesia, terutama mahasiswa sudah mulai menerima budaya luar yang masuk ke Indonesia. Namun, apabila terdapat pembahasan mengenai topik-topik yang menyinggung budaya luar, sebagian responden berkomentar bahwa netizen Indonesia masih memaksakan pendapat, menyinggung, menasihati, dan mengatur sesama saat membahas topik yang menyimpang budaya Indonesia, seperti LGBTQ+ community, atheisme, gaya hidup hedonisme dan materialistik, kehidupan bebas yang dipengaruhi budaya barat, liberalisme, dan komunisme. Hal ini menunjukan bahwa masyarakat sudah bisa menerima budaya luar yang masuk ke Indonesia, tetapi tidak bisa menerimanya dengan baik.

Penerimaan budaya yang kurang baik ini menyebabkan terjadinya berbagai hal, terutama pada media sosial, seperti sering terjadinya cyber bullying, yang dapat berdampak pada mereka yang berpendapat pada topik-topik tersebut di media sosial. Menurut para responden, seharusnya masyarakat Indonesia berpendapat hal yang sesuai di mata hukum, serta dengan kata-kata yang dapat membangun dan memperhatikan norma sosial.

Indonesia merupakan negara dimana masyarakatnya memiliki kebebasan untuk berpendapat. Namun, perlu diketahui bahwa kebebasan berpendapat juga ada batasannya. Dalam pasal 19 ayat 2 Undang-Undang Nomor 12 Tahun 2005, tertulis bahwa kebebasan berpendapat dan berekspresi ada batasannya, guna untuk menjaga keamanan nasional dan menghargai hak pribadi orang lain.

\section{Cara Menyikapi Budaya Luar yang Menyimpang di Indonesia}

Budaya-budaya luar yang menyimpang dari budaya Indonesia tidak dapat dihindari lagi akibat dari cepatnya laju persebaran informasi oleh globalisasi dan media sosial. Untuk itu, hal yang dapat dilakukan oleh masyarakat Indonesia untuk menyikapi budaya tersebut adalah untuk menjaga agar budaya tersebut tidak diadopsi masyarakat Indonesia namun tetap bersikap toleran terhadap budaya tersebut. Selain itu, diperlukan juga edukasi mengenai budaya-budaya tersebut agar masyarakat Indonesia tidak semerta-merta menolak budaya tersebut tanpa mengetahui budaya tersebut dan aspek apa dari budaya tersebut yang menyimpang dengan paham dan budaya yang ada di Indonesia. Hal ini juga sejalan dengan tanggapan-tanggapan dari para responden dimana 26 dari 45 responden yang kami lakukan survei menyatakan bahwa meskipun budaya tersebut tetap perlu ditentang oleh masyarakat Indonesia, diperlukan edukasi lebih lanjut mengenai topik-topik tersebut kepada masyarakat serta perlunya sikap toleransi terhadap masyarakat luar yang menganut budayabudaya tersebut.

Untuk menjaga agar budaya-budaya luar yang menyimpang tersebut tidak teradopsi ke dalam masyarakat Indonesia diperlukan penguatan nilai-nilai kebudayaan Indonesia pada masyarakat Indonesia terutama pada generasi mudanya. Hal ini dikarenakan generasi muda merupakan penerus dan pewaris bangsa. Penguatan nilai-nilai kebudayaan 
tersebut dapat dilakukan dengan cara melakukan pendidikan identitas bangsa serta kebudayaan lokal yang ada di Indonesia kepada generasi muda Indonesia. Hal ini dapat dilakukan oleh para tenaga pengajar, ahli keagamaan dan kebudayaan, orang tua dan anggota keluarga, serta dari generasi muda itu sendiri. Pendidikan mengenai penguatan nilai-nilai budaya tersebut dapat membantu generasi muda untuk dapat mengembangkan dan mengkreasikan budaya-budaya Indonesia sekaligus membantu generasi muda untuk bisa menempatkan batas-batas apa yang boleh diperbuatnya (Irmania et al., 2021).

\section{KESIMPULAN}

Dari penulisan jurnal ini, didapatkan bahwa golongan remaja dengan rentang usia 16-24 tahun di Indonesia mayoritas memiliki pikiran yang terbuka dan memiliki kecenderungan untuk mentoleransi budaya luar dengan memilih untuk tidak berkomentar secara tidak relevan dan menjaga etis dalam berkomentar. Golongan remaja mayoritas berpendapat bahwa komentar yang tidak relevan adalah komentar yang menyinggung orang lain (tidak terbatas oleh kriteria tertentu) (82.2\%), memaksakan pendapat $(77.8 \%)$, dan memulai kericuhan (68.9\%).

Remaja di Indonesia $86.7 \%$ setuju berkomentar secara relevan bukan berarti bertindak apatis terhadap orang lain. Dengan menjaga kedamaian, hak dan kewajiban dalam berpendapat masingmasing individual, media sosial dapat menjadi tempat yang aman, konstruktif, dan tepat guna. Remaja di Indonesia juga mayoritas $(82.2 \%)$ setuju bahwa dengan adanya kebebasan berpendapat di media sosial dapat mengubah norma dan prinsip masyarakat di Indonesia. Remaja di Indonesia lebih mengetahui banyak hal tentang budaya luar, entah budaya tersebut tabu atau tidak. Respon remaja Indonesia juga kini jauh lebih toleran dan berpikiran terbuka terhadap perbedaan pandangan atau prinsip hidup yang ada. Akan tetapi, mayoritas (46.7\%) juga setuju bahwa kebebasan dalam berkomentar pada saat ini masih kurang sesuai karena banyak pelanggaran batasan dalam berkomentar. Netizen di Indonesia memang memiliki kebebasan dalam berpendapat, hanya saja banyak yang belum tahu bahwa kebebasan dalam berpendapat tidak berarti tidak ada batasan. Ada hak dan kewajiban yang harus diperhatikan oleh netizen di Indonesia dalam menggunakan pendapatnya.

Setelah mendapatkan data dan analisis dari topik ini, para penulis menyarankan metode pengumpulan data dengan target yang lebih banyak dan dengan kategori yang lebih luas supaya pembaca dapat mengambil manfaat dengan tidak terbatas pada identitas (dalam kasus ini adalah umur) dari pembaca. Lalu, disarankan untuk melakukan survey dengan periode waktu yang lebih lama dari 1 minggu dan tidak lebih lama dari 1 bulan supaya data dapat tetap valid dan up-todate.

Puji syukur kehadirat Tuhan Yang Maha Esa yang telah melimpahkan rahmatNya sehingga kami dapat menyelesaikan jurnal berjudul "Pengaruh Kebebasan Berpendapat menggunakan Media Sosial terhadap Norma yang Berlaku di Kalangan Anak Muda Indonesia".

Pada kesempatan ini, kami menyampaikan terima kasih atas segala doa dan bantuan beberapa pihak yang telah mendukung kami menyelesaikan karya tulis ilmiah ini. Kami mengucapkan terima kasih kepada:

1. Bapak Harry Nuriman, M.Si. selaku dosen pengampu mata kuliah Pancasila dan Pendidikan Kewarganegaraan atas bimbingan, nasihat, serta dukungan yang telah diberikan kepada kami dalam menulis dan menyusun karya tulis ilmiah ini. 
2. Para responden atas kesediaannya meluangkan waktu mengisi angket dan membantu kami dalam mengumpulkan data.
3. Orang tua yang senantiasa memberikan doa dan dukungan moral sehingga kami dapat menyelesaikan karya tulis ilmiah ini tanpa kesulitan yang berarti.

\section{DAFTAR PUSTAKA}

Asmaran As. (2002). Pengantar Studi Akhlak. Jakarta: PT Raja Grafindo

Banyumurti, I. (2019). Presentasi: Internet, media sosial, dan literasi digital. Slide Share. https://www2.slideshare.net/banyumurti/materi-1-tot-literasidigital-internet-mediasosial-dan-literasi-digital

Cahyono, A. S. (1). (2016). PENGARUH MEDIA SOSIAL TERHADAP PERUBAHAN SOSIAL MASYARAKAT DI INDONESIA. Jurnal PUBLICIANA, 9(1), 140-157. Retrieved from https://journal.unita.ac.id/index.php/publiciana/article/view/79

Effendi, M. (2010). Peranan Internet Sebagai Media Komunikasi. Jurnal Dakwah dan Komunikasi Vol. 4 No. 1.

Franz magnis Suseno. 1993. Etika dasar. Jakarta: Pustaka Filsafat.

Haryatmoko. 2007. Etika Komunikasi. Indonesia: Kanisius.

K Bertens. (1993). Etika. Jakarta: Gramedia. h. 22

Maulinda, R., Suyatno. Etika Komunikasi dalam Menggunakan Media Sosial (Instagram). 4-7.

Niken Sitoresmi. (2021). Pembatasan Hak Berekspresi Harus Ketat dan Tidak Sewenangwenang. 13 November 2021, pukul 12:50 WIB. https://www.komnasham.go.id/index.php/news/2021/6/15/1816/pembatasan-hakberekspresi-harus-ketat-dan-tidak-sewenang-wenang.html

Nugroho, Y. (2008). Adopting Technology, Transforming Society: The Internet and the Reshaping of Civil Society Activism in Indonesia. International Journal of Emerging Technologies and Society Vol.6 No.22, Jakarta

Nurgiansah, T. H. (2018). Pengembangan Kesadaran Hukum Berlalu Lintas Siswa Melalui Model Pembelajaran Jurisprudensial Dalam Pendidikan Kewarganegaraan (Studi Kasus di SMK Bina Essa Kabupaten Bandung Barat Kelas X Administrasi Perkantoran). Tesis. Repository Universitas Pendidikan Indonesia, Oktober. http://ieeeauthorcenter.ieee.org/wpcontent/uploads/IEEE-Reference-

Guide.pdf\%0Ahttp://wwwlib.murdoch.edu.au/find/citation/ieee.html\%0Ahttps://doi.or g/10.1016/j.cie.2019.07.022\%0Ahttps://github.com/ethereum/wiki/wiki/White-

Paper\%0Ahttps://tore.tuhh.de/hand

Nurgiansah, T. H. (2020). Filsafat Pendidikan. In Banyumas: CV Pena Persada.

Nurgiansah, T. H. (2021). Pendidikan Pancasila. In Solok: CV Mitra Cendekia Media.

Rachman, F., Nurgiansah, T. H., \& Kabatiah, M. (2021). Profilisasi Pendidikan Kewarganegaraan dalam Kurikulum Pendidikan Indonesia. Edukatif: Jurnal Ilmu Pendidikan, 3(5), 29702984.

Rachman, F., Ryan, T., Kabatiah, M., Batubara, A., Pratama, F. F., \& Nurgiansah, T. H. (2021). Pelaksanaan Kurikulum PPKn pada Kondisi Khusus Pandemi Covid-19. Jurnal Basicedu, 5(6), 5682-5691.

Scholte, J.A. (2005). Globalization: A Critical Introduction. 2nd Edition. London: Palgrave Macmillan

Tomlinson, J. (1999). Globalization and Culture. Cambridge: Polity Press. 